\title{
Parental unemployment and child health in China
}

\author{
Janneke Pieters ${ }^{1} \cdot$ Samantha Rawlings (D) $^{2}$
}

Received: 14 September 2018 / Accepted: 7 June 2019 / Published online: 23 June 2019

(c) The Author(s) 2019; This article is published with open access at Springerlink.com

\begin{abstract}
This paper studies the causal effect of maternal and paternal unemployment on child health in China, analyzing panel data for the period 1997-2004, when the country underwent economic reforms leading to massive layoffs. Using a FE-IV strategy, we find that paternal unemployment reduces child health, while maternal unemployment has beneficial child health impacts. Analysis of channels shows that paternal and maternal unemployment have different effects on income, time use, and children's diets. Though many estimates are imprecise, a key finding is that paternal unemployment significantly reduces children's fat intake and dietary diversity. To the best of our knowledge, this is the first evidence on the causal effect of parental unemployment on the nutrient intake of children aged $0-17$. In all, our estimates are consistent with the notion that traditional gender roles can explain why mothers' and fathers' unemployment affect child health differently.
\end{abstract}

Keywords Child Health · Unemployment · Nutrition · China

JEL Classification I12 $\cdot \mathrm{J} 13 \cdot \mathrm{J} 69 \cdot \mathrm{O} 15$

\section{Introduction}

Healthy development of children is an important concern across societies, as illustrated by the Sustainable Development Goals' targets for reducing child stunting and wasting. Despite considerable gains in height and weight amongst children, estimates suggest that in 2015, 50 million infants $(7.5 \%)$ were wasted and 159 million infants $(23.8 \%)$ were stunted (UNICEF 2015). Moreover, a vast amount of evidence suggests that childhood health influences health and economic outcomes later in life

Samantha Rawlings

s.b.rawlings@reading.ac.uk

1 Development Economics Group, Wageningen University, Hollandseweg 1, 6706 KN Wageningen, The Netherlands

2 Department of Economics, University of Reading, PO Box 219 WhiteknightsReading RG6 6AA, UK 
(Case and Paxson 2010; Currie et al. 2010; Almond and Currie 2011), so that any economic shock or policy reform that impacts children's health has potentially long lasting economic and social impacts.

An important channel through which macroeconomic conditions and policy reforms affect child health is through parental employment. The association between parental employment and child health can be explained from a simple model of child health production, where parents invest both time inputs and material inputs in child health (Currie 2009). A loss of employment is typically associated with income and substitution effects that operate in different directions (Ferreira and Schady 2009). Unemployment will lower income available for spending on market goods, including health care, non-household child care, and nutritious consumption, whilst lowering the opportunity cost of time so that we might observe increases in home-produced and time-intensive health investments. ${ }^{1}$

Available evidence on the child health impacts of macroeconomic conditions indeed suggests an important role for parental employment, particularly mothers' labor supply. Bhalotra (2010) shows that in rural India, infant mortality is countercyclical, because recessions push rural women (but not men) into the agricultural labor force and reduce their use of health care. On the other hand, Miller and Urdinola (2010) find that child mortality in Colombia is pro-cyclical, as reductions in the global coffee price are associated with lower employment for women and increases in prenatal care and child vaccinations. ${ }^{2}$ It thus appears that substitution effects associated with changes in maternal employment dominate the child health impacts of macroeconomic cycles, but the existing studies do not provide direct evidence on the causal effect of paternal and maternal employment on child health in developing countries. Considering aggregate employment opportunities (as opposed to parental employment directly), Page et al. (2019) consider the relationship between labour market conditions and child health in the US. They find improved female employment prospects lead to reduced health, whilst improved male employment improves it, and provide evidence consistent with the notion that income effects dominated time effects for men, whilst the opposite is true for women.

Differences in the impacts of maternal and paternal unemployment on children have been studied in most detail in relation to child schooling outcomes. RuizValenzuela (2015), investigating the impact of the Great Recession in Spain, finds that fathers' unemployment negatively affects child attainment in school whilst unemployment of mothers has no statistically significant effect. Rege et al. (2011), using plant closures in Norway, find that fathers' job loss leads to a substantial

\footnotetext{
${ }^{1}$ In line with this, recent evidence from the US suggests that the substitution effect dominates the income effect amongst low wage individuals (Agostinelli and Sorrenti, 2018).

${ }^{2}$ Further available evidence suggests that infant mortality in the US is pro-cyclical (Dehejia and LlerasMuney, 2004), and being born during a recession improves childhood health in Western Europe (Angelini and Mierau, 2014). Recent evidence from the US however suggests differential effects depending on household type, finding that income shocks experienced due to the Great Recession affected health expenditure on children in single-mother families but not dual-parent households (Monheit et al. 2018).
} 
decline in children's graduation-year grade point average whilst mothers' job loss leads to non-significant improvements in school performance. They argue this is consistent with recent evidence suggesting men suffer an increase in mental distress as a result of job loss, and that maternal job loss induces less mental distress than paternal job loss (Kuhn et al. 2009). They also suggest that the positive effect of maternal job loss indicates that mothers respond by allocating greater attention towards child rearing. Kalil and Ziol-Guest (2008) reach similar conclusions from the analysis of children's academic progress in the US.

In this paper we analyze how paternal and maternal unemployment affect the health of children aged 0-17 in China. During the period 1990-2010 the percentage of stunted and underweight children under 5 in China fell from 32 and 13\%, respectively, to 9.4 and 4\%, but large regional and socio-economic disparities remain (WHO 2014). We analyze child health in the period 1997 to 2004, when the restructuring of state owned enterprises had major labor market impacts, which have been documented widely (e.g. Cai et al. 2008; Meng 2012). As the reforms led to massive layoffs and sharp reductions in labour force participation rates, it provides an excellent setting to study the child health impacts of parental unemployment in a developing country context.

Our paper is closely related to two recent studies on parental unemployment and child health in the US and Sweden. Schaller and Zerpa (2019), using panel data for children aged 1-16 from the US medical expenditure survey, find that paternal unemployment reduces parent-rated child physical and mental health, while increasing the likelihood of depression and anxiety. Maternal unemployment also reduces parent-rated child health, but reduces the incidence of infectious diseases and the use of prescription drugs. The unemployment effects are identified based on child fixed effects and a focus on displacements due to business closures. Evidence based on administrative data from Sweden (Mork et al. 2014) shows that maternal unemployment is associated with a small increase in hospitalization of children aged 3-18, while paternal unemployment has no significant effect. Mork et al. (2014) control for child fixed effects in their estimations, but as they are not able to distinguish different causes of unemployment, their estimates might be confounded. Job loss may be correlated with unobserved time-varying determinants of child health, for example if parents of children with poor health progression are more likely to quit work, or if parental productivity shocks affect both job loss and child health (Rege et al. 2011).

We use the China Health and Nutrition Survey (CHNS), a panel survey with individual, household, and community level data, including measures of health, nutrition, income, and employment. Availability of anthropometric data for children is an important advantage of the CHNS data: unlike Schaller and Zerpa (2019) and Mork et al. (2014), we do not rely solely on medical care utilization or parent-rated health measures that may confound health with other determinants of diagnosis and treatment.

In a third recent paper closely related to ours, Liu and Zhao (2014) find a negative association between child health and fathers' and mothers' recent job loss (the event of losing one's job) during the period 1991-2006 in China, although the effect of maternal job loss is statistically insignificant. An important conceptual difference with the present paper is that Liu and Zhao (2014) estimate the effect of recent job 
loss, rather than unemployment (or joblessness). ${ }^{3}$ We see no reason to believe that parents' time use and income are affected only by job loss, rather than joblessness and in this paper we focus on joblessness. They also focus on separate estimations for maternal and paternal job loss, only controlling for presence of the other parent in the household, which is potentially endogenous. Instead, we restrict our sample to households in which both parents are present and include the employment status of both parents in each estimation. This results in larger effect sizes of either parent's unemployment.

Our analysis includes individuals across eight provinces for the period 1997-2004, when we observe a strong reduction in employment rates, in line with trends reported from other data sources for China. We estimate child fixed effects models and, to account for time varying unobservables, we instrument parental unemployment using sex-specific employment rates in the household's county or city of residence. The identification thus comes from local employment fluctuations, and we rule out several other channels by controlling for local average earnings and several indicators of local health infrastructure and economic infrastructure. Similar approaches, exploiting regional labor market fluctuations, have been used in the analysis of schooling choices (Pinger 2015) and returns to education (Carneiro et al. 2011), among others.

In line with Schaller and Zerpa (2019), we find that paternal unemployment increases the incidence of low weight-for-age. On the other hand, maternal unemployment reduces the incidence of low weight-for-age, and significantly lowers both the probability that a child has been sick or injured in the last four weeks, and the probability that health care was sought in the last four weeks.

To assess the channels through which unemployment affects child health, we estimate the impact of unemployment on household income, health insurance, time use of parents and children, and child diets. Though our estimates are imprecise, the results are in line with the notion that traditional gender roles drive the differential unemployment impacts of mothers and fathers. Paternal unemployment leads to a large and significant drop in household income, and maternal unemployment significantly reduces children's time on domestic chores. Descriptive statistics for our estimation sample confirm that women earn less than men and spend considerably more time on caring for young children and on domestic chores.

Turning to child diets, which we analyze as indicators of child health investments, we find that maternal unemployment increases children's dietary diversity score (an indicator of the nutrient adequacy of diets), whereas paternal unemployment reduces children's dietary diversity score, and reduces the intake of fats. To the best of our knowledge, this is the first study to investigate the causal effect of parental unemployment on the quality of children's diets, and the results suggest that this is one of the channels through which parental unemployment affects child health.

\footnotetext{
3 They regress current child health on an indicator for whether the mother or father lost his or her job between the previous and current period; this indicator then switches back to zero in the next period, regardless of whether the parent is re-employed or remains unemployed. Their estimates therefore show the association between the event of losing a job and current child health, rather than the effect of parental unemployment.
} 
The rest of the paper is organized as follows. Section 2 discusses the reforms in China and evidence of their impact on employment, and briefly outlines the theoretical framework. Section 3 describes the data, Section 4 describes the methodology, and Sections 5 and 6 discuss the main results and analysis of heterogeneity. Section 7 concludes.

\section{Context and theoretical framework}

\subsection{China's economic reforms and the labor market}

In this paper we focus on a time period when China reformed its State Owned Enterprise (SOE) sector, in the second half of the 1990s. The reforms had major impacts on the labor market, which we exploit to identify the impacts of parental unemployment on child health. In 1994, the Chinese government initiated the privatization of small and medium SOEs, but initially, the government maintained tight control of worker lay-offs (Cai et al. 2008). The end of guaranteed employment followed when, in 1997, a more aggressive SOE restructuring program was implemented to deal with the sector's unsustainable financial situation. As a result, millions of workers were laid off from the state and collective sector through dismissals and forced early retirement. The labor force participation rate declined drastically, especially among women and the population aged 40-60 (Giles et al. 2006, Cai et al. 2008). According to Zhang et al. (2008), who use data from the China Urban Household Survey for the period 1988-2004, the employment rate of men and women aged 16 to 60 fell from around 96 percent in 1997 to 89 percent (men) and 80 percent (women) in 2003. The rates reported in Zhang et al. (2008) are plotted in Fig. 1. SOE restructuring has most strongly affected industries with highly competitive markets or depleted resources. The traditional industrial bases in the Northeast and Northwest were therefore the hardest hit regions, with the majority of layoffs occurring in Liaoning, Jilin, Heilongjiang, Hubei, Hunan, Henan, and Sichuan provinces (Dong 2003).

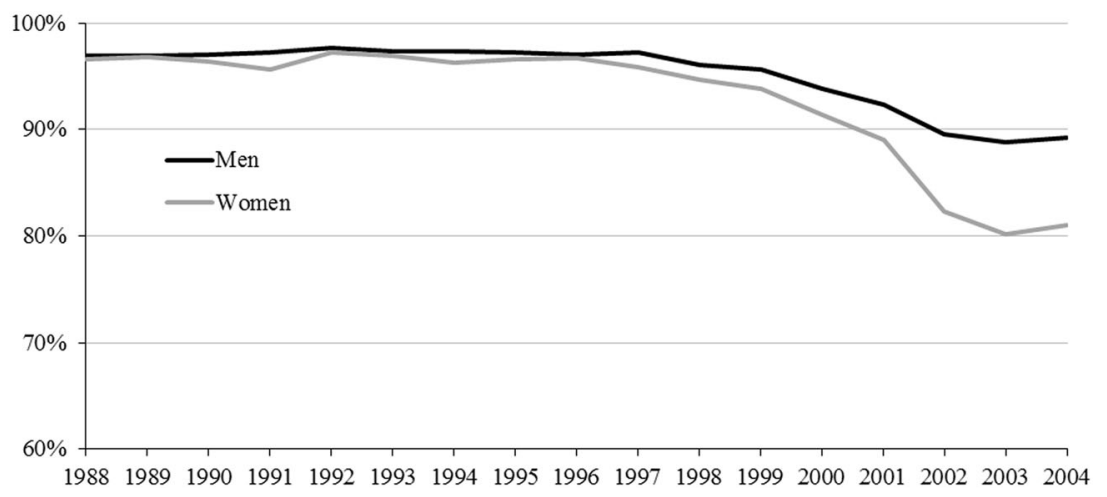

Fig. 1 Urban employment rate, 1988-2004. Source: China Urban Household Survey, as presented in Zhang et al. (2008, Table 1a) 
In 1998 the Chinese government implemented a special social assistance program, providing subsidies, training, and job search assistance to workers laid-off under the SOE restructuring program. However, data collected in five Chinese cities by Giles et al. (2006) show that these public programs had limited coverage and that most unemployed relied on the support of other members in their household and on their own savings. The program was a transitional arrangement that was merged in to general unemployment insurance (UI), which was introduced in urban areas in 1999. This officially covered urban and rural workers employed by urban enterprises, who are entitled to a lump sum living allowance if they have over one year of continuous service and if their employers have paid the UI contribution (Vodopivec and Tong 2008). However, there is evidence that many employers do not fulfil their obligations, especially towards rural migrant workers (World Bank 2007). Aside from these urban schemes, evidence from Cook (2002) suggests that within rural areas there were limited unemployment schemes and coverage was lacking. Hence, becoming unemployed during this period meant a significant economic shock to the individual and his or her household.

\subsection{Theoretical framework}

To assess the child health impacts of parental unemployment, it is useful to start from the standard economic model of child health production as described by Currie (2009), in which child health is a source of household utility. Parents use both time inputs and material inputs to invest in child health; child health at time $t$ further depends on past health, on exogenous productivity shifters, and on permanent individual productivity shifters. Productivity shifters affect the amount of health obtained from a given amount of health inputs: an example is years of formal schooling (Grossman 2000).

In this framework, parental unemployment will affect child health through a number of channels. First of all, it reduces the income available for spending on market goods such as health care (including private health insurance), non-household child care, and nutritious consumption. This may reduce the quantity as well as the quality of material child health inputs. Second, unemployment reduces the opportunity cost of time so that we might observe increases in the quantity and quality of home-produced and time-intensive health investments. Unemployment may also reduce expenditure on health due to the loss of health insurance coverage if employer provided insurance coverage is lost.

Each of these channels can play a role in explaining why maternal unemployment would affect child health differently than paternal unemployment. Firstly, because fathers tend to have higher earnings than mothers, the income loss associated with paternal unemployment is typically greater. The increase in parental time investments in child health, on the other hand, might be greater for women, given traditional gender roles dictating that mothers are primarily responsible for child care and other household tasks (Kalil and Ziol-Guest 2008; Rege et al. 2011). Traditional gender roles can also mediate the impact of unemployment on psychosocial stress, as suggested by evidence of stronger gender differences in mental health effects of unemployment between married men and women than between single men and women (Artazcoz et al. 2004). 


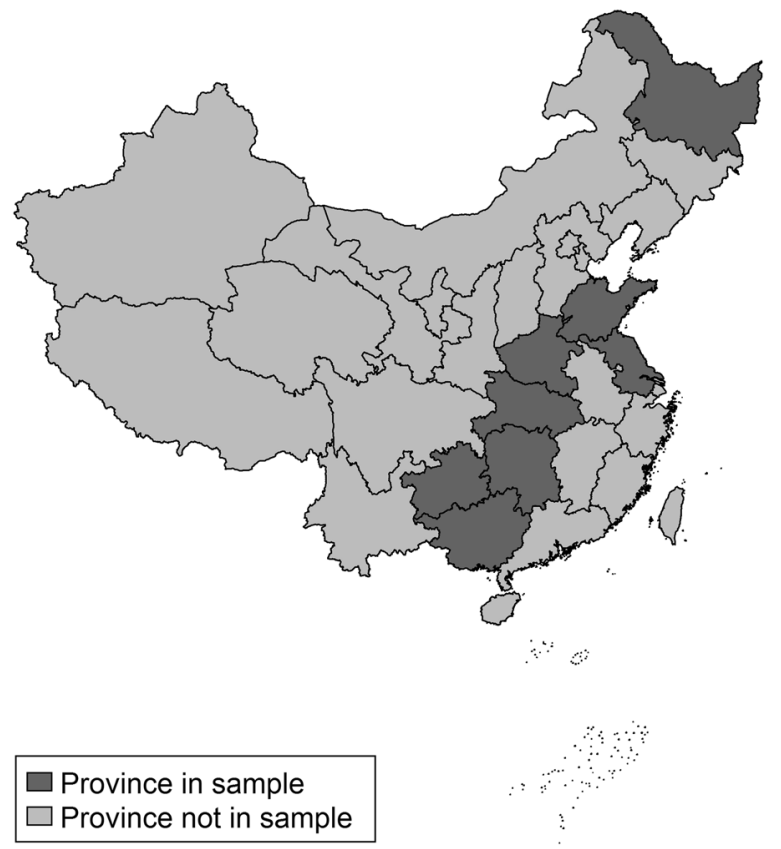

Fig. 2 Map of provinces in analysis

\section{Data}

The analysis uses the China Health and Nutrition Survey (CHNS), an open cohort panel survey. ${ }^{4}$ The data covers nine provinces and three province level municipalities and was collected in nine waves between 1989 and 2011. We use data for 8 provinces that were included in the three waves of 1997, 2000, and 2004, the period we analyze; Guangxi, Guizhou, Heilongjiang, Henan, Hubei, Hunan, Jiangsu, and Shandong. ${ }^{5}$ Figure 2 shows the provinces used in the analysis; they vary in terms of geographical location, demographics, economics and health indicators. Note that despite this variation, the sample was not intended to be a representative sample of the whole of China, though there is some evidence to suggest that characteristics of households and individuals in the data are comparable to those from national samples (Chen et al. 2015).

The data contain comprehensive measures of health and diets, as well as information on demographic and socioeconomic characteristics, income, and time use. We discuss the measures used in our analysis below, and provide summary statistics on the main variables in Table 1. Unfortunately, the CHNS do not collect information

\footnotetext{
${ }^{4}$ See http://www.cpc.unc.edu/projects/china for information on and access to the data.

5 An additional province, Liaoning, was unfortunately dropped from the analysis in one of our rounds of interest - 1997 - and thus is not used in the analysis. In 2011, three province level municipalities were added to the sample: Beijing, Shanghai, and Chongqing. These areas are not included in our data due to no information being available for our period of interest.
} 
Table 1 Summary statistics

\begin{tabular}{|c|c|c|c|c|c|}
\hline Variable & Mean & Std. Dev. & Min. & Max. & $N$ \\
\hline Age & 9.924 & 3.939 & 0 & 17 & 4222 \\
\hline Male & 0.541 & 0.498 & 0 & 1 & 4222 \\
\hline Weight for age z-score & -0.841 & 1.132 & -4.93 & 4.313 & 4222 \\
\hline Low weight-for-age & 0.149 & 0.357 & 0 & 1 & 4222 \\
\hline Sick or injured during last 4 weeks & 0.045 & 0.207 & 0 & 1 & 4122 \\
\hline Used health service last 4 weeks & 0.064 & 0.244 & 0 & 1 & 3936 \\
\hline Child health insurance & 0.188 & 0.39 & 0 & 1 & 4023 \\
\hline Log carbohydrates $(\mathrm{g})$ & 5.508 & 0.439 & 1.351 & 6.586 & 3950 \\
\hline $\log$ fat $(g)$ & 3.799 & 0.690 & -0.916 & 5.188 & 3950 \\
\hline Log proteins $(\mathrm{g})$ & 3.897 & 0.434 & 1.125 & 4.928 & 3950 \\
\hline Dietary diversity & 4.034 & 0.974 & 1 & 6 & 3950 \\
\hline Mother jobless & 0.16 & 0.367 & 0 & 1 & 4222 \\
\hline Father jobless & 0.067 & 0.25 & 0 & 1 & 4222 \\
\hline Household income (2011 Yuan) & 6923 & 12381 & 0 & 198630 & 4222 \\
\hline Child's time on chores (min. per day) & 6.874 & 23.173 & 0 & 214 & 3328 \\
\hline Mother's time on chores & 130.8 & 83.62 & 0 & 455 & 4222 \\
\hline Father's time on chores & 17.37 & 38.70 & 0 & 210 & 4222 \\
\hline Community clinics & 0.886 & 0.734 & 0 & 6 & 4222 \\
\hline Community hospitals & 0.354 & 0.6 & 0 & 3 & 4222 \\
\hline Comm. infrastructure index & -0.008 & 1.01 & -2.755 & 1.983 & 4222 \\
\hline
\end{tabular}

Low weight-for-age is defined as having a z-score for weight-for-age of less than -2 . Children's time on chores is recorded only for children aged 6 and older

on mental health, so that it is not possible for us to investigate whether parental stress is a channel through which parental unemployment affects child health.

\subsection{Health}

The CHNS collects a number of indicators of health status of children. We use weight-for-age of children, an indicator for low weight-for-age (weight z-score < -2 ), whether they have been sick or injured in the last four weeks, and an indicator for whether the child used health services in the last 4 weeks. We do not investigate height-for-age since this reflects permanent measures of health and is determined in large part by inputs between the ages of 0-2 (Hoddinott and Kinsey 2001). Given the short nature of our panel, we instead focus on weight-for-age. Weight is measured by trained health professionals, avoiding bias associated with self-reported measures of health.

Weight-for-age z-scores are calculated with reference to US child growth standards. ${ }^{6}$

\footnotetext{
${ }^{6}$ Z-scores are calculated using the Stata command -zanthro- and the US 2000 CDC growth reference. A WHO reference is available as well, but allows calculating weight-for-age z-scores only for children age $0-10$, which is a smaller age range then we use in our estimations. Our results for weight-for-age are robust to using the WHO reference, which produces very similar z-scores.
} 
Weight captures contemporaneous health and reflects both muscle and fat content; this can change rapidly according to nutrition. We also calculate an indicator for low weight-for-age (weight-for-age $<2$ s.d. below reference mean). ${ }^{7}$ According to these indicators, 15 percent of children in our sample have low weight-for-age (Table 1).

Besides current health, parents are also asked about the incidence of sickness or injuries of their children, and whether their child accessed a health service during the past four weeks, as well as the type of service received (a general or child health exam, a blood test, blood pressure screening, tumor screening, or vision or hearing exam). In our sample, 4.5 percent of children were sick or injured during the past four weeks and 6.4 percent received some type of health service during the same period. In almost $85 \%$ of cases where a child received a health service, this was a general health or child health examination. It is not clear from the data, unfortunately, to what extent these examinations are used for preventive care or for diagnosis or treatment. Almost 19 percent of children are covered by some form of (private or public) medical insurance.

\subsection{Nutrition}

We analyze a number of child nutrition indicators, which we consider to capture a type of health investment that is likely to be affected by parents' income and time use. While there are studies on the relationship between maternal employment and breastfeeding (see, for example, Baker and Milligan 2008), we are not aware of studies that analyze the effect of parental unemployment on nutrition of older children. Whilst anthropometric indicators are typically used as indicators of children's nutritional status, individual level data on nutrition are often not available. An advantage of the CHNS data is that we have information on dietary intake.

Data on dietary intake is collected in the CHNS survey through a combination of three consecutive 24-hour recalls at the individual level and a food inventory at the household level performed over the same three day period. For the individual recall data, individuals were interviewed on three consecutive days (randomly allocated from Monday to Sunday) and reported all food consumed at home and away from home. A food inventory at the household level was used to check individual recall, with all foods in the household weighed on a daily basis and changes in food inventory as well as estimated waste used to estimate total household food consumption. ${ }^{8}$ Data on the resulting individual macronutrient intake values based on these dietary data-average daily intake of protein, fat, and carbohydrates-are available in the public use CHNS data.

In addition, we calculate dietary diversity scores for the children in our sample, with use of China's 1991, 2002, and 2004 Food Composition Tables, based on the individual dietary data recorded. First, all foods consumed are grouped into six food categories. These are starches; vegetables and fruit; meat and fish; eggs; legumes,

\footnotetext{
7 Although here we focus on weight-for-age exclusively, our results are robust to using an indicator for underweight (defined as grade 1, 2, or 3 category thinness, according to international cut-offs for agespecific BMI (Cole et al., 2007)). We do not use this in our main analysis since it is only available for children aged 2-18. Results available on request.

${ }^{8}$ More specific detail on the collection of dietary data is given in Batis et al. (2014) and Xu et al. (2015).
} 
nuts and seeds; and milk and milk products. Next, the dietary diversity score is calculated as the number of different food groups that were consumed over the past three days by the child, ranging from zero to six. Dietary diversity scores reflect the nutrient adequacy of diets, and although they have been validated for different countries and age groups, there is no international consensus on the number and type of food groups to include in the scores for different age groups (FAO 2010). Recent evidence for children age 1 to 9 in South Africa suggests that scores based on 6, 9, 13, and 21 food groups are all highly correlated to micronutrient diet adequacy and significantly correlated with height-for-age and weight-for-age (Steyn et al. 2014). The average score in our sample is 4.03 , with a standard deviation of close to 1 .

\subsection{Employment, income, and time use}

The CHNS further collects employment details and income of all persons aged 16 and older (18 and older as of the 2004 wave), as well as household level farming and non-farm business income. In our analysis, we consider a work status transition from working to not working as job loss. This includes dismissals as well as retirement and voluntary quits, but unfortunately we do not have data on the reason for losing one's job. The CHNS data does include information on whether a person is looking for a job. However, if we would only consider individuals actively searching for work as unemployed, we would exclude all so-called discouraged workers (those who move from being employed to being out of the labor force altogether). Discouraged workers are formally not part of the labor force and therefore not officially considered unemployed in international statistics, but we prefer to include them in our analysis, as large scale economic reforms are likely to increase disguised unemployment through discouragement (World Bank 2007). ${ }^{9}$ Another way to put this is that we are interested in the impact of parents being out of work, whether or not they are actively searching for a job.

In the CHNS sample of males age 25-55 and females age 25-50, the employment rate as a fraction of the labor force (i.e. excluding any discouraged workers) declined by three to four percentage points between 1997 and 2004 (Fig. 3a), with a slightly stronger decline for men than women. Employment rates stabilize after 2004. Figure $3 \mathrm{~b}$ shows that employment as a fraction of the population (including discouraged workers) fell by 12 percentage points for men and 15 percentage points for women between 1997 and 2004. Comparing Fig. 3a, b, it is clear that the fraction of men and women searching for work increased less than the fraction of men and women out of the labor force: the majority of working age individuals without employment reported doing housework or "other", while only 11 to 19 percent reported looking for a job.

Though the direct impact of the reforms was strongest in urban China and most research on the impacts of SOE restructuring has focused on urban labor markets, we find similar trends in employment rates in the urban and rural sample (Fig. 4),

\footnotetext{
9 For example, one study in two cities in China found that 2 years after being laid off, $50 \%$ of workers laid off due to the SOE restructuring had excited the labour force by official definitions (i.e., they were not searching for a job), $25 \%$ were officially unemployed, and $25 \%$ had secured further employment (Betcherman and Blunch, 2008).
} 

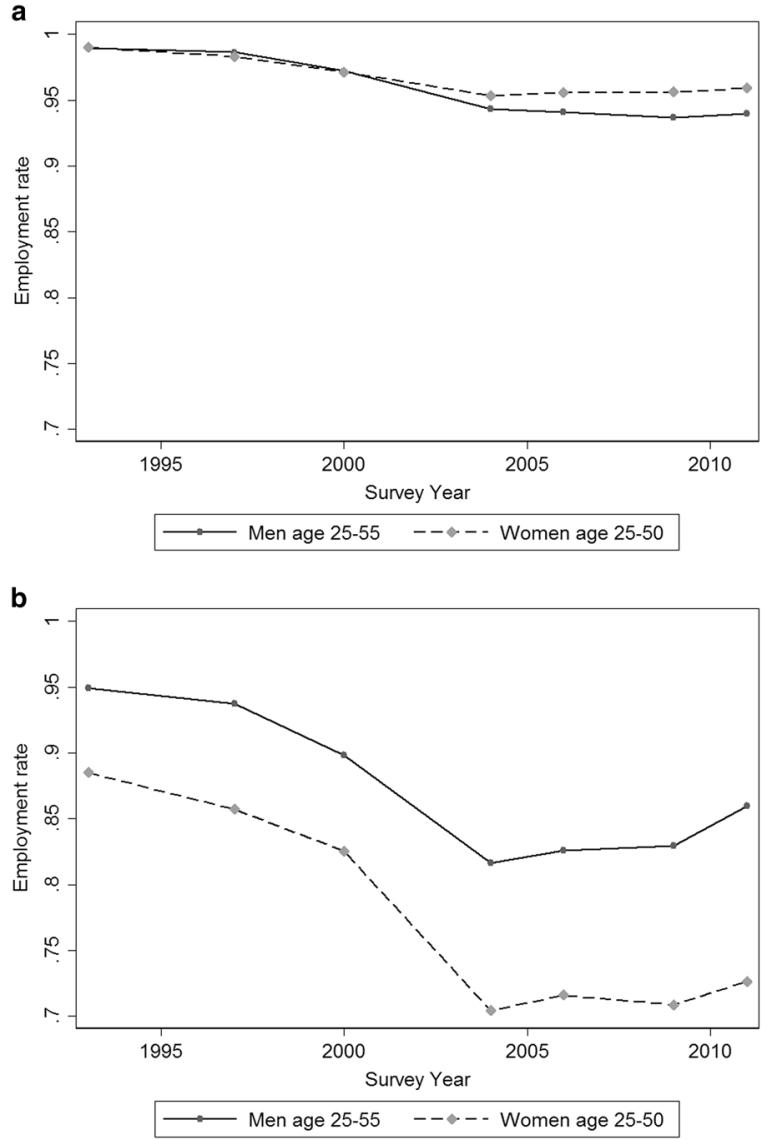

Fig. 3 Employment rates CHNS data, 1993-2011. a Employment share of labor force. b Employment share of population

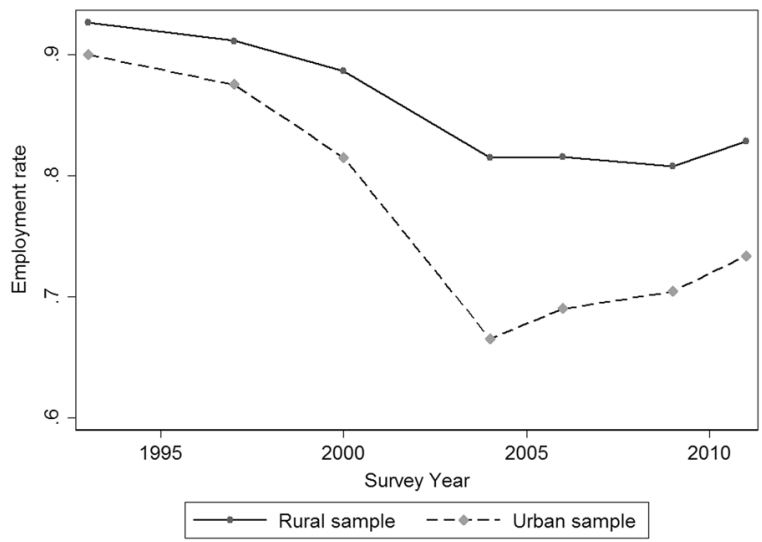

Fig. 4 Rural and urban employment rate (\% of population) CHNS data, 1993-2011 
reflecting the fact that SOE retrenchment also occurred in county/rural SOE (Dong 2003; Bramall 2007), and that rural migrants were also affected by SOE retrenchment since they were often forced to vacate their posts to enable re-employment of laid off urban workers (Gold et al. 2009). The trend is less pronounced in the rural sample, but still shows a reduction of about 10 percentage points between 1997-2004. Besides the trends in the CHNS data, competition for jobs between urban workers and rural migrants as well as some degree of labor market integration between the public, collective, and private sectors (Dong and Bowles 2002), suggest that rural workers were not isolated from the reforms. We therefore include both urban and rural families in our analysis. Households classified as rural in the CHNS come from both suburban rural areas of county towns as well as more rural villages. In our estimation sample, mothers are jobless in 16 percent of child-wave observations and fathers in 6.7 percent.

The CHNS records various sources of income, including agricultural income, nonagricultural income, subsidies and other incomes. We focus on income from earnings, which equals zero for individuals without wage employment. ${ }^{10}$ Among individuals with positive earnings, fathers in our sample earn about $25 \%$ more $(10,700$ Yuan per month) than mothers (8,400 Yuan). We thus expect that households will experience greater losses in earnings with paternal unemployment than with maternal unemployment.

Time use data is collected for all individuals aged 6 and older. However, data on time use are limited; rather than a full time use survey, individuals report average minutes per day during the past week spent on a variety of activities. Time use on domestic activities is collected for the following categories: buying food for the household, preparing and cooking food for the household, washing and ironing clothes, and cleaning the house. We add the last three of these together to construct a measure of time spent on domestic chores over the past week. ${ }^{11}$ Children aged 6 and older spend on average 6.9 min per day on domestic chores, while mothers spend $130 \mathrm{~min}$ per day and fathers spend $17 \mathrm{~min}$.

Though time spent on child care is also recorded, this only relates to care for children aged 6 and younger, so that our sample is too small to analyze effects of unemployment on child care. It is useful to note, however, that mothers of young children in our sample are much more likely to care for these children than fathers are, and also spend more hours per week: for children younger than age 6 in the 1997 CHNS wave, 74 percent of mothers indicate they spend time on child care, compared to 38 percent of fathers. Conditional on providing any child care, mothers spend on average $13.9 \mathrm{~h}$ per week while fathers spend $6.1 \mathrm{~h}$ per week. Overall, as the time use of mother and fathers shows a strong traditional gender division of household work, we expect to find that maternal unemployment has greater time use effects benefiting child health, as discussed in Section 2.2.

\footnotetext{
${ }^{10}$ Our results are qualitatively similar if we use total household income across all sources, which is sometimes imputed based on information either from previous waves for the same household, or provincelevel means for the current wave, for particular categories of income; results available on request.

11 We exclude time on buying food for the household, since buying and preparing food are substitutes to some extent. Our results are similar when buying food is included; results available on request.
} 


\subsection{Community data}

As we further discuss below, we include a number of control variables to capture local health infrastructure and economic infrastructure in our estimations. These variables are constructed from the CHNS community data, which were collected through questionnaires to a knowledgeable respondent on community infrastructure, services, population, etc. Communities (the primary sampling units in the CHNS) are villages or townships within counties (rural) or neighborhoods within cities (urban). From the community services module we use the number of health clinics and the number of hospitals in the community. From the infrastructure module we create an index of economic infrastructure, calculated as the standardized sum of seven indicators (whether the community has a large store; a free market; any paved roads; a bus stop; a train station nearby; electricity on all days of the week; a child care facility). The index is based on Jones-Smith and Popkin (2010), missing values were imputed using province-level means.

\section{Methodology}

Our specification of interest is:

$$
\begin{aligned}
H_{i j k t}= & \alpha_{i}+\beta_{1} \text { Jobless }_{i j k t}^{f}+\beta_{2} \text { Jobless }_{i j k t}^{m}+\beta_{3} X_{i j k t}+\beta_{4} C_{j k t} \\
& +\beta_{5} W_{k t}+\beta_{6} \gamma_{t}+\beta_{7} Y_{i j k t} \gamma_{t}+\epsilon_{i j k t}
\end{aligned}
$$

Our dependent variable $H_{i j k t}$ is health of child $i$, observed in community $j$ in citycounty $k$, in wave $t(1997,2000$, or 2004). Our primary health measures of interest are the weight-for-age $\mathrm{z}$-score of the child, and an indicator for low weight-for-age (z-score $<2$ s.d. below reference mean). We further analyze indicators for whether the child was sick or injured and whether the child received any health services during the past four weeks. Our explanatory variables of interest are indicators for whether the father $(f)$ or mother $(m)$ was jobless in wave $t$. We estimate child fixed effects models $\left(\alpha_{i}\right)$, to account for time-invariant characteristics at the child level such as inherent healthiness. Survey wave fixed effects $\left(\gamma_{t}\right)$ are included in all specifications, controlling for China-wide trends in child health. We also include a vector of time varying child and parent controls $X_{i j k t}$ including age of the child, age of both parents, and number of children in the household. Note we do not know exactly when parents lose their job, only whether they are jobless in survey wave $t$, so that our FE results, rather than estimating the 'instantaneous' effect of unemployment, capture the average effect of unemployment with a duration of 1 day up to 4 years (the maximum time period between consecutive survey waves) on current health.

Identification within this framework relies on the assumption that job loss is uncorrelated with unobserved time-varying child health determinants, which may not be the case. For example, an unobserved (to the researcher) deterioration in child health could increase the likelihood of parents quitting their job. To address this issue, we exploit spatial variation in the labor market impacts of the reforms to instrument parental job loss. Fathers' employment status is instrumented by the male employment rate in the household's city (urban) or county (rural) of residence; similarly, we instrument 
maternal employment status using the city- and county-level female employment rate. Our estimation sample contains 48 cities and counties, and in all estimations we report standard errors clustered at the city or county level. Note that permanent local labor market conditions are controlled for through the child fixed effects. In addition, we control for the average city/county log monthly earnings $W_{k t}$ to capture local labor market conditions that may affect child health aside from parental joblessness, and particularly through earnings, rather than employment. We further control for a vector of community level variables $C_{j k t}$ that includes an index of the community's economic infrastructure, the number of clinics in the community, and the number of hospitals in the community, as described above (Section 3.4). These variables are intended to capture changes in local development and (health) infrastructure that may be correlated with employment rate fluctuations, while also affecting the health of children.

Ultimately, our identification strategy relies on the assumption that, conditional on local average monthly earnings and local development and (health) infrastructure, employment shocks in the local labor market affect child health outcomes only through parental employment. Similar approaches, exploiting regional labor market fluctuations, have been used in the analysis of schooling choices (Pinger 2015) and returns to education (Carneiro et al. 2011), among others. Unlike those studies, we focus on a time period characterized by economic reforms to ensure, as much as possible, that changes in employment are driven by these reforms rather than for example general improvements in economic conditions that might reduce female employment through negative income effects. ${ }^{12}$ One potential effect of local employment shocks that we cannot control for is increased stress from uncertainty. The CHNS data do not contain indicators for mental health or subjective wellbeing. If parents experience stress from fear of losing their job, this could negatively affect child health even if parents keep their jobs. Our estimates may, therefore, be negatively biased. As we will see, we find that paternal unemployment generally reduces child health while maternal unemployment leads to better health outcomes. Where paternal unemployment has significant negative health impacts, our point estimates are generally large and thus unlikely to be driven entirely by ambient stress, but the potential negative bias should still be kept in mind when interpreting the results. It should not, however, affect the differential between mothers' and fathers' unemployment effects.

We report separate estimates that also include controls for initial household wealth and parental education, interacted with dummies for survey wave $\left(Y_{i j k t} \gamma_{t}\right){ }^{13}$ Wealth and education can be considered productivity shifters in the production of child health, affecting the level of child health produced for given levels of material and time inputs (see Currie 2009). ${ }^{14}$ Differential trends in health according to initial

\footnotetext{
$\overline{12}$ Note that we do not control for lagged child health, as we would lose a large fraction of our estimation sample and we would need to instrument for lagged health given the inclusion of child fixed effects. However, our main interest is in the effect of parental job loss, and the potential correlation of lagged child health with job loss would be addressed through the instrumental variable estimation.

13 To measure household wealth, we use an asset index based on housing conditions and ownership of vehicles and durable goods. The index is calculated using polychoric principal components analysis, as described in Ward (2014).

14 We focus on initial wealth and education here, since current wealth and education of parents may be endogenous. This further ensures that our unemployment estimates are not biased by correlations between initial education and wealth levels with subsequent labor market fluctuations.
} 
parents' education and wealth thus capture differences in the impacts of macroeconomic changes on child health. As productivity shifters may similarly affect impacts of unemployment on child health, we also analyze heterogeneity by household socio-economic status. This is discussed in Section 6.

We restrict our sample to children who were born in or before 1997 (the first wave we use) and no older than age 17. These age restrictions are motivated by two selection concerns. First of all, if the reforms affect fertility decisions in some way that is correlated with determinants of child health, selective fertility may bias our estimates by changing the composition of children born into the sample after 1997. We therefore only include children born in or before $1997 .{ }^{15}$ Second, for children aged 18 and older, the percentage of children who have moved out of their parental household increases substantially. Their health indicators are not collected: we thus use the upper age limit to prevent selection bias associated with the endogenous decision of children to leave their parental household. Even with these age restrictions, selective mortality could affect our estimates if the least healthy children in the sample died before 2004. Yet on inspection of the data we find that of the 3,388 children who meet our sample restrictions, only 21 died between 1997 and 2004, so this is highly unlikely to affect our estimates.

For the fixed effects estimations we need to observe each child at least twice, which gives a total of 6,412 child-wave observations. ${ }^{16} \mathrm{We}$ further exclude 550 observations where the parents reach retirement age (50 years old for women; 55 years old for men) before 2004, to focus as much as possible on joblessness unrelated to retirement. The same age limits are used in construction of the instruments (but note that men and women without children or with children outside the age range indicated above are also included when constructing the city/county level employment rates). We focus on children with both parents reporting their work status and with both parents present in the household, which further reduces the sample size to 4,445 child-waves. ${ }^{17}$ And finally, due to some missing values for our basic control

\footnotetext{
15 Our results are robust to the inclusion of children born after 1997; results available on request.

${ }^{16}$ We do not observe all children in all waves. Of the 3,388 children who meet our initial sample restrictions, 2581 (76.18\%) participate in all three waves, and 807 children drop out of the sample. Of these 807 , one third (234) are lost from the sample due to becoming older than 17. The remaining 573 children ( $16.9 \%$ of those who meet our original sample restrictions) are lost due to attrition, in line with the general level of attrition observed in the CHNS data (Popkin et al., 2009). Attrition may bias our results if it is affected by parental job status or our instruments. We investigated this using probit regressions with the dependent variable indicating if a child was missing in a particular wave, and found that attrition is not related to either initial employment status of the parent, or changes between waves in male or female employment rates in the child's city/county of residence.
}

17 Of our initial sample of 3,388 children, 663 (19.57\%) have one or both parents who are either absent from the survey in later waves or are listed on the household roster as living elsewhere. These children are excluded from our analysis, and this may result in selection bias if mobility of parents is related to parental job status or our instruments. We investigated this using separate probit regressions with the dependent variable indicating if a mother or father was missing in a particular wave. Results suggested that neither employment status in 1997 nor changes in city or county employment rates between waves were drivers of subsequent mobility of mothers or fathers. Furthermore, our results are robust to inclusion of children for whom we observe the working status of parents who live outside the household; results available on request. 
variables, the final estimation sample includes at most 4,222 child-wave observations (for 1,838 children). ${ }^{18}$ In this final estimation sample, 162 mothers and 97 fathers become unemployed between the 1997 and 2000 wave, while 146 mothers and 68 fathers lose their job between 2000 and 2004 .

\section{Results}

\subsection{Main Results}

We first estimate the effect of paternal and maternal unemployment on child health indicators. Table 2 shows effects on child weight. Columns (I) and (IV) show fixed effects OLS estimation results; the remaining columns show fixed effects IV estimations. In all cases we include basic control variables, while columns (III) and (VI) additionally allow for differential trends according to initial household wealth and parental education.

The results show that the effect maternal unemployment tends to be in opposite direction of the effect of paternal unemployment. If we focus on the IV estimates including the full set of control variables (columns III and VI), we find no significant impacts on weight-for-age (the estimates are large but imprecisely estimated), while the incidence of low weight-for-age decreases significantly with maternal unemployment and increases significantly with paternal unemployment. The negative effect of maternal unemployment on low weight-for-age is statistically significant only at the ten percent level and only if we include the additional control variables. Paternal unemployment significantly increases low weight-for-age in all specifications.

First-stage results show that the instruments are highly significant, and the Fstatistic is sufficiently high. The coefficients indicate that a percentage point decline in the local female employment rate increases the probability of a mother being jobless by almost 0.8 percentage points, while a percentage point decline in the local male employment rate increases fathers' joblessness by about 1 percentage point. Coefficients for control variables are not shown, in the interests of space, but we find that the average local monthly wage, the number of clinics and hospitals in the community, and the economic infrastructure index do not significantly affect health outcomes. Furthermore, the coefficient estimates for parental joblessness are not affected by including these controls, suggesting that local employment rate fluctuations did not affect child health through the general wage development, or local changes in (health) infrastructure and facilities. ${ }^{19}$

\footnotetext{
${ }_{18}$ For all outcomes, we restrict our sample to those children for whom weight-for-age could be measured. Our sample size may still vary across outcomes, since we sometimes have missing values for dependent variables. Our results are robust to restricting to a common sample across dependent variables. Results available on request.

19 We find it somewhat reassuring that neither the city/county level average earnings nor the community level control variables have a significant effect on our measures of child health, which suggests that parental employment is really the primary channel through which labor market fluctuations affect child health. This is consistent with recent evidence from the US that suggests there is no relationship between aggregate economic conditions and child health (Page et al. 2019).
} 
Table 2 Effect of parental unemployment on child health

\begin{tabular}{|c|c|c|c|c|c|c|}
\hline & \multicolumn{3}{|c|}{ Weight-for-age } & \multicolumn{3}{|c|}{ Low Weight-for-age } \\
\hline & (I) & (II) & (III) & (IV) & (V) & $(\mathrm{VI})$ \\
\hline & FE & FE-IV & FE-IV & $\mathrm{FE}$ & FE-IV & FE-IV \\
\hline Mother Jobless & $\begin{array}{l}0.017 \\
(0.059)\end{array}$ & $\begin{array}{l}0.481 \\
(0.325)\end{array}$ & $\begin{array}{l}0.435 \\
(0.311)\end{array}$ & $\begin{array}{l}0.013 \\
(0.019)\end{array}$ & $\begin{array}{l}-0.111 \\
(0.075)\end{array}$ & $\begin{array}{l}-0.124 * \\
(0.074)\end{array}$ \\
\hline Father Jobless & $\begin{array}{l}-0.187 * * \\
(0.090)\end{array}$ & $\begin{array}{l}-0.757 * * \\
(0.333)\end{array}$ & $\begin{array}{l}-0.466 \\
(0.368)\end{array}$ & $\begin{array}{l}0.037 * \\
(0.021)\end{array}$ & $\begin{array}{l}0.265 * * * \\
(0.094)\end{array}$ & $\begin{array}{l}0.214 * * \\
(0.102)\end{array}$ \\
\hline$N$ & 4222 & 4222 & 4222 & 4222 & 4222 & 4222 \\
\hline$P$-value F-test & 0.104 & 0.037 & 0.144 & 0.495 & 0.016 & 0.034 \\
\hline F-stat first stage & & 29.130 & 36.156 & & 29.130 & 36.156 \\
\hline \multicolumn{7}{|c|}{ First stage-mother jobless } \\
\hline $\begin{array}{l}\text { Female } \\
\text { employment rate }\end{array}$ & & $\begin{array}{l}-0.773 * * * \\
(0.126)\end{array}$ & $\begin{array}{l}-0.792 * * * \\
(0.120)\end{array}$ & & $\begin{array}{l}-0.773 * * * \\
(0.126)\end{array}$ & $\begin{array}{l}-0.792 * * * \\
(0.120)\end{array}$ \\
\hline $\begin{array}{l}\text { Male } \\
\text { employment rate }\end{array}$ & & $\begin{array}{l}-0.092 \\
(0.155)\end{array}$ & $\begin{array}{l}-0.091 \\
(0.146)\end{array}$ & & $\begin{array}{l}-0.092 \\
(0.155)\end{array}$ & $\begin{array}{l}-0.091 \\
(0.146)\end{array}$ \\
\hline \multicolumn{7}{|c|}{ First stage-father jobless } \\
\hline $\begin{array}{l}\text { Female } \\
\text { employment rate }\end{array}$ & & $\begin{array}{l}0.137 \\
(0.094)\end{array}$ & $\begin{array}{l}0.125 \\
(0.096)\end{array}$ & & $\begin{array}{l}0.137 \\
(0.094)\end{array}$ & $\begin{array}{l}0.125 \\
(0.096)\end{array}$ \\
\hline $\begin{array}{l}\text { Male } \\
\text { employment rate }\end{array}$ & & $\begin{array}{l}-1.062 * * * \\
(0.174)\end{array}$ & $\begin{array}{l}-1.029 * * * \\
(0.172)\end{array}$ & & $\begin{array}{l}-1.062 * * * \\
(0.174)\end{array}$ & $\begin{array}{l}-1.029 * * * \\
(0.172)\end{array}$ \\
\hline Basic controls & $\mathrm{Y}$ & Y & $\mathrm{Y}$ & $\mathrm{Y}$ & Y & $\mathrm{Y}$ \\
\hline $\begin{array}{l}\text { Additional } \\
\text { controls }\end{array}$ & $\mathrm{N}$ & $\mathrm{N}$ & $\mathrm{Y}$ & $\mathrm{N}$ & $\mathrm{N}$ & Y \\
\hline
\end{tabular}

All estimations include child fixed effects. $N$ refers to the number of child-waves in the estimation. $P$-value $F$-test refers to the F-test that the coefficients for mother and father jobless are equal. Basic control variables are survey wave fixed effects, age of the child, age of both parents, number of children in the household, local average monthly wages, the local economic infrastructure index, and the number of clinics and hospitals in the community. Additional control variables are initial household wealth and parental education, interacted with survey wave dummies. 'Weight-for-age' is the child's z-score for weight-forage; 'Low Weight-for-age' is an indicator for whether weight-for-age $<2$ s.d. below the reference mean. Standard errors clustered by city/county are in parentheses. ***significant at 1 percent level, **significant at 5 percent level, *significant at 10 percent level

Table 3 shows estimated effects on additional health measures. We further find that mothers' unemployment is associated with a 13.8 percentage point reduction in the probability that a child has been sick or injured in the last 4 weeks, and a 16.8 percentage point reduction in the probability that the child used health services in the last 4 weeks. ${ }^{20}$ The effect of fathers' unemployment on sickness and health care use is positive but not statistically significant.

To summarise, our main estimates suggest that paternal unemployment negatively affects the anthropometric health of children, especially the probability of a child having low weight-for-age (at least 2 standard deviations below the age- and sex-

\footnotetext{
${ }^{20}$ As discussed in Section 3.1, the question asked in the CHNS relates to general health and child health examinations, which could reflect preventive investments as well as investments in diagnosis and treatment. Given the effects of unemployment on children's health and sickness during the past four weeks (in Table 3), the estimates for health services are more likely to reflect a response to changes in health.
} 
Table 3 Effect of parental unemployment on additional measures of child health

\begin{tabular}{|c|c|c|c|c|c|c|}
\hline & \multicolumn{3}{|c|}{ Sick/Injured last 4 weeks } & \multicolumn{3}{|c|}{ Health services } \\
\hline & (I) & (II) & (III) & (IV) & $(\mathrm{V})$ & (VI) \\
\hline & $\mathrm{FE}$ & FE-IV & FE-IV & $\mathrm{FE}$ & FE-IV & FE-IV \\
\hline Mother Jobless & $\begin{array}{l}-0.001 \\
(0.015)\end{array}$ & $\begin{array}{l}-0.160 * * \\
(0.080)\end{array}$ & $\begin{array}{l}-0.138^{*} \\
(0.076)\end{array}$ & $\begin{array}{l}-0.049^{* *} \\
(0.019)\end{array}$ & $\begin{array}{l}-0.174 * * \\
(0.077)\end{array}$ & $\begin{array}{l}-0.168 * * \\
(0.077)\end{array}$ \\
\hline Father Jobless & $\begin{array}{l}-0.014 \\
(0.018)\end{array}$ & $\begin{array}{l}0.070 \\
(0.070)\end{array}$ & $\begin{array}{l}0.063 \\
(0.066)\end{array}$ & $\begin{array}{l}0.030 \\
(0.030)\end{array}$ & $\begin{array}{l}0.236 \\
(0.194)\end{array}$ & $\begin{array}{l}0.274 \\
(0.203)\end{array}$ \\
\hline$N$ & 4122 & 4122 & 4122 & 3936 & 3936 & 3936 \\
\hline$P$-value F-test & 0.665 & 0.081 & 0.107 & 0.035 & 0.058 & 0.055 \\
\hline F-stat first stage & & 25.539 & 33.239 & & 27.801 & 34.994 \\
\hline \multicolumn{7}{|c|}{ First stage-mother jobless } \\
\hline $\begin{array}{l}\text { Female } \\
\text { employment rate }\end{array}$ & & $\begin{array}{l}-0.777 * * * \\
(0.136)\end{array}$ & $\begin{array}{l}-0.803 * * * \\
(0.129)\end{array}$ & & $\begin{array}{l}-0.832 * * * \\
(0.130)\end{array}$ & $\begin{array}{l}-0.849 * * * \\
(0.125)\end{array}$ \\
\hline $\begin{array}{l}\text { Male } \\
\text { employment rate }\end{array}$ & & $\begin{array}{l}-0.095 \\
(0.153)\end{array}$ & $\begin{array}{l}-0.081 \\
(0.145)\end{array}$ & & $\begin{array}{l}-0.023 \\
(0.151)\end{array}$ & $\begin{array}{l}-0.026 \\
(0.140)\end{array}$ \\
\hline \multicolumn{7}{|c|}{ First stage_-father jobless } \\
\hline $\begin{array}{l}\text { Female } \\
\text { employment rate }\end{array}$ & & $\begin{array}{l}0.136 \\
(0.092)\end{array}$ & $\begin{array}{l}0.124 \\
(0.095)\end{array}$ & & $\begin{array}{l}0.128 \\
(0.089)\end{array}$ & $\begin{array}{l}0.117 \\
(0.091)\end{array}$ \\
\hline $\begin{array}{l}\text { Male } \\
\text { employment rate }\end{array}$ & & $\begin{array}{l}-1.060 * * * \\
(0.171)\end{array}$ & $\begin{array}{l}-1.025^{* * * *} \\
(0.166)\end{array}$ & & $\begin{array}{l}-1.054 * * * \\
(0.175)\end{array}$ & $\begin{array}{l}-1.022 * * * \\
(0.167)\end{array}$ \\
\hline Basic controls & $\mathrm{Y}$ & $\mathrm{Y}$ & $\mathrm{Y}$ & $\mathrm{Y}$ & Y & $\mathrm{Y}$ \\
\hline $\begin{array}{l}\text { Additional } \\
\text { controls }\end{array}$ & $\mathrm{N}$ & $\mathrm{N}$ & $\mathrm{Y}$ & $\mathrm{N}$ & $\mathrm{N}$ & $\mathrm{Y}$ \\
\hline
\end{tabular}

All estimations include child fixed effects. $N$ refers to the number of child-waves in the estimation. $P$-value $F$-test refers to the F-test that the coefficients for mother and father jobless are equal. Basic control variables are survey wave fixed effects, age of the child, age of both parents, number of children in the household, local average monthly wages, the local economic infrastructure index, and the number of clinics and hospitals in the community. Additional control variables are initial household wealth and parental education, interacted with survey dummies. Standard errors clustered by city/county are in parentheses. ***significant at 1 percent level, **significant at 5 percent level, *significant at 10 percent level

specific reference mean) while maternal unemployment reduces the probability of a child having low weight-for-age. Maternal unemployment further improves other indicators of child health, including the incidence of sickness or injuries and use of health services. ${ }^{21}$ The difference between the coefficients on Mother Jobless and Father Jobless is statistically significant in most of the IV estimations. These results are in line with findings for the US by Schaller and Zerpa (2019), who partly rely on subjective child health as reported by parents and on medical care use.

Appendix Table 9 shows estimates when we consider mother and father unemployment in isolation from one another. The pattern of results is very similar, but coefficient sizes are smaller, suggesting the importance of conditioning on both parents' employment status. In our sample, paternal and maternal joblessness are positively correlated, and since they turn out to have opposite impacts on child

\footnotetext{
${ }^{21}$ For about 20 percent of child-wave observations in our estimation sample, one or more grandparents live in the child's household. Our results are nearly identical when controlling for presence of grandparents in the household (results are available from the authors).
} 
health, not controlling for the other parent's employment status results in attenuation bias.

\subsection{Channels}

As discussed in Section 2.2 unemployment is expected to affect child health through changes in income, time use, and access to health insurance, each of which may differ between paternal and maternal unemployment. To investigate these channels, we estimate the following equation:

$$
\begin{aligned}
C_{i j k t}= & \alpha_{i}+\beta_{1} \text { Jobless }_{i j k t}^{f}+\beta_{2} \text { Jobless }_{i j k t}^{m}+\beta_{3} X_{i j k t} \\
& +\beta_{4} C_{j k t}+\beta_{5} W_{k t}+\beta_{6} \gamma_{t}+\beta_{7} Y_{i j k t} \gamma_{t}+\epsilon_{i j k t}
\end{aligned}
$$

This is the same specification as Eq. (1), but we replace our measures of child health with our potential channels of interest. Again, all estimations include child fixed effects and we instrument joblessness with city/county level sex-specific employment rates. Following the outline of the theoretical framework, we start with analysis of income, health insurance coverage, and time use. We then turn to the effects on children's diets in Section 5.2.2.

\subsubsection{Income, insurance, and time use}

Table 4 shows the effects of unemployment on income, health insurance of children, and time use of children and parents. The income estimates (column I) suggest that fathers' unemployment has a large negative effect on households' total earnings, significant at the 10 percent level. The maternal unemployment estimate is much smaller, but also very imprecise. We find no significant effect of paternal and maternal unemployment on children's health insurance (column II). This lack of

Table 4 Effect of parental unemployment on income, health insurance, and time use

\begin{tabular}{llllll}
\hline & (I) & (II) & (III) & (IV) & (V) \\
& Income & Health insurance & Child chores & Mother chores & Father chores \\
& FE-IV & FE-IV & FE-IV & FE-IV & FE-IV \\
\hline Mother Jobless & $-1918.664(4296.584)$ & $-0.212(0.246)$ & $-33.402^{* * *}(12.844)$ & $12.387(52.180)$ & $-14.390(17.251)$ \\
Father Jobless & $-8467.988^{*}(5079.173)$ & $-0.303(0.249)$ & $13.056(15.056)$ & $-64.383(59.592)$ & $5.209(24.472)$ \\
$N$ & 4222 & 4023 & 3328 & 4222 & 4222 \\
P-value F-test & 0.432 & 0.817 & 0.044 & 0.458 & 0.578 \\
F-stat first stage & 36.156 & 38.911 & 18.940 & 36.156 & 36.156 \\
Basic controls & $\mathrm{Y}$ & $\mathrm{Y}$ & $\mathrm{Y}$ & $\mathrm{Y}$ & $\mathrm{Y}$ \\
Additional controls & $\mathrm{Y}$ & $\mathrm{Y}$ & $\mathrm{Y}$ & $\mathrm{Y}$ & $\mathrm{Y}$ \\
\hline
\end{tabular}

Notes: All estimations include child fixed effects. $N$ refers to the number of child-waves in the estimation. $P$-value $F$-test refers to the F-test that the coefficients for mother and father jobless are equal. Basic control variables are survey wave fixed effects, age of the child, age of both parents, number of children in the household, local average monthly wages, the local economic infrastructure index, and the number of clinics and hospitals in the community. Additional control variables are initial household wealth and parental education, interacted with survey dummies. Standard errors clustered by city/county are in parentheses. ***significant at 1 percent leve, *significant at 10 percent level 
significance is not that surprising, given the Chinese context, as during our time period the link between child health insurance coverage and parental employment was weak. Insurance levels in rural areas have historically been low since the collapse of the Co-operative Medical Scheme (CMS) in the period following the economic reforms of 1978, so that only 9 percent of rural residents had coverage under the CMS in 2003 (Chen et al. 2011). Although the New Co-operative Medical Scheme (NCMS) was introduced in some pilot areas in 2003, this was not nationally rolled out until 2007 (Zhang et al. 2010), which occured after the time frame in our sample (1997-2004). ${ }^{22}$ Furthermore, coverage through the NCMS is low, with only catastrophic health care coverage covered until 2007 (Yang 2013). Although urban formal sector workers would be covered by the publicly provided Basic Medical Insurance (BMI) from 1998 onwards, this did not cover dependents and urban children were not covered by public medical insurance until the introduction of Urban Resident Basic Medical Insurance (URBMI) in 2007 (Lin et al. 2009). ${ }^{23}$

Columns III to V show the impact of unemployment on time allocation within the household; we use the average minutes per day spent on domestic chores (washing, cleaning, and preparing food) by the mother and father, as well as the child. The time use of children is available only for children aged 6 and older, resulting in a smaller estimation sample. As results in column (III) show, maternal unemployment reduces the time that children spend on domestic chores by 33 min per day. The estimated effect is large relative to the mean in the sample; the sample average is $6.9 \mathrm{~min}$ per day, whilst the corresponding figure conditional on doing any domestic chores is $38.8 \mathrm{~min}$ with a standard deviation of 42.3 . We do not find significant changes in the time that parents spend on domestic chores (columns IV and V). If we restrict the estimation sample for parents' time use to include only the parents of children aged 6 and older (those included in column III) we find similar results; maternal unemployment frees up children's time but there are no statistically significant effects on time use of mothers or fathers themselves.

Appendix Tables 10 and 11 shows results for income, health insurance, and time use, when mother and father joblessness is considered in isolation. Once again, the results are broadly similar, but estimates are stronger whenever the effect of mothers' and fathers' joblessness goes in the same direction, and attenuated when they go in opposite direction. For health insurance, for example, the estimates are about 50 percent larger when we do not control for the other parent's job status, and the effect of fathers' unemployment becomes statistically significant.

In all, bearing in mind that income is always difficult to measure, and the limited scope of time use data, the evidence is fairly weak but nonetheless suggests that different channels may explain the differential health effects of paternal and maternal unemployment. The strongest evidence relates to children's time use, where the

\footnotetext{
22 As a robustness check, we do investigate whether our results are robust to inclusion of a dummy for whether the NCMS was available in the community of residence, and results were unchanged. Results available on request.

23 The BMI was introduced in 1998, whereas our sample begins in 1997. Prior to the introduction of the BMI, some children in our sample may have been covered by the Labor Insurance Scheme (LIS), so that job loss in that first year may have been associated with a loss in insurance. However, dependents were not always covered by the LIS, and when covered they received only partial coverage (Liu 2002), so that it is unlikely a large fraction of our sample, which is predominantly rural, would be affected by this.
} 
effect of maternal unemployment differs significantly from that of paternal unemployment.

\subsubsection{Children's diets}

Income and time use are considered key channels linking parental unemployment to child health, as they determine the resources available to parents for investing in child health. We now turn to an analysis of one particular area of these health investments, that of child diets.

Results for children's macronutrient intake (carbohydrates, fats, and proteins) and dietary diversity are reported in Table 5. The effect of maternal unemployment on children's macronutrient intake is insignificant, but maternal unemployment increases children's dietary diversity score by 0.6 , significant at the 10 percent level (Column IV). Paternal unemployment, on the other hand, significantly reduces children's intake of fat by around 1 standard deviation (as reported in Table 1) and reduces dietary diversity by 0.9 . Coefficients for other nutrients are also negative but not statistically significant. A declining share of energy from dietary fat may lead to insufficient fat intake for children's growth needs. Chunming (2000) reports that, based on a survey conducted in China in 1991, stunting among boys younger than six was linked with a low intake of protein and fat. Yet there seems to be no conclusive evidence on the effect of low fat intake on growth. Our results suggest that reduced fat intake and dietary diversity play a role in the negative child health effects of paternal unemployment, while increased dietary diversity may be a channel through which maternal joblessness improves child health. Appendix Table 12 shows results when mother and father joblessness are considered in isolation. Once again, the results are broadly similar, but coefficient sizes are considerably different when we fail to consider the unemployment status of the other parent.

Table 5 Effect of parental unemployment on child diets

\begin{tabular}{|c|c|c|c|c|}
\hline & $\begin{array}{l}\text { (I) } \\
\text { Carbohydrates } \\
\text { FE-IV }\end{array}$ & $\begin{array}{l}\text { (II) } \\
\text { Fats } \\
\text { FE-IV }\end{array}$ & $\begin{array}{l}\text { (III) } \\
\text { Protein } \\
\text { FE-IV }\end{array}$ & $\begin{array}{l}\text { (IV) } \\
\text { Dietary diversity } \\
\text { FE-IV }\end{array}$ \\
\hline Mother Jobless & $-0.090(0.220)$ & $-0.132(0.349)$ & $0.038(0.160)$ & $0.624 *(0.369)$ \\
\hline Father Jobless & $-0.143(0.396)$ & $-0.803 *(0.412)$ & $-0.288(0.305)$ & $-0.987 * *(0.462)$ \\
\hline$N$ & 3950 & 3950 & 3950 & 3950 \\
\hline $\mathrm{P}$-value F-test & 0.922 & 0.347 & 0.418 & 0.042 \\
\hline F-stat first stage & 32.426 & 32.426 & 32.426 & 32.426 \\
\hline Basic controls & $\mathrm{Y}$ & $\mathrm{Y}$ & $\mathrm{Y}$ & $\mathrm{Y}$ \\
\hline Additional controls & Y & $\mathrm{Y}$ & $\mathrm{Y}$ & $\mathrm{Y}$ \\
\hline
\end{tabular}

Carbohydrates, fats and proteins are measured in log grams. The dietary diversity (DD) score ranges from 0 to 6. All estimations include child fixed effects. $N$ refers to the number of child-waves in the estimation. $P$-value F-test refers to the F-test that the coefficients for mother and father jobless are equal. Basic control variables are survey wave fixed effects, age of the child, age of both parents, number of children in the household, local average monthly wages, the local economic infrastructure index, and the number of clinics and hospitals in the community. Additional control variables are initial household wealth and parental education, interacted with survey dummies. Standard errors clustered by city/county are in parentheses. **significant at 5 percent level, *significant at 10 percent level 


\section{Heterogeneity}

In this section we explore whether the health effects of parental job loss differ by households' socio-economic status, and analyze heterogeneity by children's sex and across rural and urban areas.

\subsection{Socio-economic status of the parents}

Our estimations so far controlled for the initial level of household wealth and parental education, each interacted with year dummies, in order to capture productivity shifters in child health production. As explained in Section 4, these may also affect the impact of unemployment on child health. In the basic theoretical framework of child health production, one would expect that negative income effects and positive substitution effects of unemployment are greater when parents have higher child health productivity. On the other hand, more wealthy households may be better able to mitigate the negative income effects. Time use shifts of more educated mothers may also be greater, for example because more educated mothers are more likely to work longer hours and to use market-based child care if they do work (Schaller and Zerpa 2019).

To assess whether children are differentially affected depending on the socioeconomic status (SES) of their household, we split the sample according to the education level of the father. Low-SES households are defined as those where the father has completed less than middle school education. ${ }^{24}$ Comparing children in low-SES and high-SES households (Table 6), we find that estimates are statistically similar. Pooled sample estimations where we interact all variables with the low-SES indicator show that estimates are never significantly different across the two subsamples, although coefficients on Father Jobless tend to be larger in magnitude in the low-SES subsample. The difference between the impact of maternal and paternal unemployment also tends to be greater in the low-SES sample, where it is statistically significant for two of the four health outcomes.

\subsection{Boys and girls}

China, like India, is well known for the phenomenon of missing women, reflecting a culturally rooted son preference (Das Gupta 2008). While skewed population sex ratios are perhaps the most visible result of son preference, it also affects parental investments in child health, as recently documented for India (Barcellos et al. 2014). In separate estimations for boys and girls (Table 7), we find that the effects of maternal and paternal unemployment on low weight-for-age and incidence of sickness tend to be stronger for girls than boys. The difference across sub-samples is not statistically significant ${ }^{25}$, but coefficient estimates are larger for girls, and they are

\footnotetext{
${ }^{24}$ Middle school was the median level of education for mothers and fathers in 1997. Results are very similar when we classify households by their asset index value or either parent's years of education, but in some cases have weaker first stage identification; results available on request.

25 Tests for the differences across subsamples were conducted using pooled sample estimations not reported here, but available from the authors.
} 
Table 6 Effect of parental unemployment on health, by father's education

\begin{tabular}{|c|c|c|c|c|}
\hline & (I) & (II) & (III) & (IV) \\
\hline & Weight-for-age & Low weight-for-age & Sick/Injured last 4 weeks & Health care use \\
\hline & FE-IV & FE-IV & FE-IV & FE-IV \\
\hline \multicolumn{5}{|c|}{ Panel A: Low education } \\
\hline Mother jobless & $0.714 *(0.398)$ & $-0.108(0.118)$ & $-0.158(0.128)$ & $-0.135(0.097)$ \\
\hline Father jobless & $-0.484(0.494)$ & $0.327 * *(0.156)$ & $0.175(0.131)$ & $0.447 * *(0.211)$ \\
\hline$N$ & 1122 & 1122 & 1092 & 1038 \\
\hline$P$-value F-test & 0.111 & 0.065 & 0.136 & 0.024 \\
\hline F-stat first stage & 10.689 & 10.689 & 11.403 & 12.558 \\
\hline \multicolumn{5}{|c|}{ Panel B: High education } \\
\hline Mother jobless & $0.331(0.390)$ & $-0.159(0.115)$ & $-0.135(0.095)$ & $-0.206^{*}(0.116)$ \\
\hline Father jobless & $-0.455(0.489)$ & $0.211(0.140)$ & $0.040(0.099)$ & $0.261(0.298)$ \\
\hline$N$ & 3098 & 3098 & 3028 & 2896 \\
\hline$P$-value F-test & 0.335 & 0.116 & 0.328 & 0.164 \\
\hline F-stat first stage & 28.386 & 28.386 & 25.130 & 25.115 \\
\hline Basic controls & $\mathrm{Y}$ & $\mathrm{Y}$ & $\mathrm{Y}$ & $\mathrm{Y}$ \\
\hline Additional controls & $\mathrm{Y}$ & $\mathrm{Y}$ & $\mathrm{Y}$ & $\mathrm{Y}$ \\
\hline
\end{tabular}

Notes: All estimations include child fixed effects and wave fixed effects. $N$ refers to the number of childwaves in the estimation. $P$-value F-test refers to the F-test that the coefficients for mother and father jobless are equal. Basic control variables are survey wave fixed effects, age of the child, age of both parents, number of children in the household, local average monthly wages, the local economic infrastructure index, and the number of clinics and hospitals in the community. Additional control variables are initial household wealth and parental education, interacted with survey dummies. Standard errors clustered by city/county are in parentheses. **significant at 5 percent level, *significant at 10 percent level

statistically significant in columns II and III while the estimates for boys are never statistically significant. Together, the pattern across outcomes is consistent in that paternal (maternal) unemployment reduces (improves) health, and this pattern is statistically significant only for girls.

\subsection{Rural and urban}

Our final heterogeneity analysis concerns rural vs. urban children. Since SOEs tend to be concentrated in urban areas (although SOE retrenchment still occurred at the county/rural level (Dong 2003; Bramall 2007)), we might expect that effects are driven by the urban sample. A drawback of the CHNS data are that only $28 \%$ of the sample are urban, which reduces our power in identifying effects for this subgroup.

Table 8 shows results when we split the sample by rural and urban location. We do not find that results are statistically different across subsamples, but an important issue is that the smaller sample size, and-on inspection of the first stage results (not shown here)-lack of predictive power of female employment rate on maternal unemployment in the urban sample leads to a small F-statistic for the urban sample so that our instruments are weak in this sub-sample. Still, we find significant effects 
Table 7 Effect of parental unemployment on health of boys and girls

\begin{tabular}{|c|c|c|c|c|}
\hline & (I) & (II) & (III) & (IV) \\
\hline & Weight-for-age & Low weight-for-age & Sick/Injured last 4 weeks & Health care use \\
\hline & FE-IV & FE-IV & FE-IV & FE-IV \\
\hline \multicolumn{5}{|l|}{ Panel A: Boys } \\
\hline Mother jobless & $0.573(0.391)$ & $-0.009(0.114)$ & $-0.062(0.089)$ & $-0.181(0.125)$ \\
\hline Father jobless & $-0.497(0.433)$ & $0.166(0.117)$ & $-0.003(0.080)$ & $0.177(0.188)$ \\
\hline$N$ & 2285 & 2285 & 2247 & 2136 \\
\hline$P$-value F-test & 0.131 & 0.411 & 0.682 & 0.187 \\
\hline F-stat first stage & 26.087 & 26.087 & 22.352 & 23.443 \\
\hline \multicolumn{5}{|l|}{ Panel B: Girls } \\
\hline Mother jobless & $0.231(0.400)$ & $-0.245 * *(0.108)$ & $-0.213 *(0.124)$ & $-0.125(0.112)$ \\
\hline Father jobless & $-0.269(0.535)$ & $0.312 * *(0.155)$ & $0.165(0.120)$ & $0.366(0.277)$ \\
\hline$N$ & 1937 & 1937 & 1875 & 1800 \\
\hline$P$-value F-test & 0.566 & 0.017 & 0.087 & 0.108 \\
\hline F-stat first stage & 27.544 & 27.544 & 29.212 & 25.250 \\
\hline Basic controls & $\mathrm{Y}$ & $\mathrm{Y}$ & $\mathrm{Y}$ & $\mathrm{Y}$ \\
\hline Additional controls & $\mathrm{Y}$ & $\mathrm{Y}$ & $\mathrm{Y}$ & $\mathrm{Y}$ \\
\hline
\end{tabular}

All estimations include child fixed effects. $N$ refers to the number of child-waves in the estimation. $P$-value $F$-test refers to the F-test that the coefficients for mother and father jobless are equal. Basic control variables are survey wave fixed effects, age of the child, age of both parents, number of children in the household, local average monthly wages, the local economic infrastructure index, and the number of clinics and hospitals in the community. Additional control variables are initial household wealth and parental education, interacted with survey dummies. Standard errors clustered by city/county are in parentheses. **significant at 5 percent level, *significant at 10 percent level

of maternal unemployment on child health in the rural sample, suggesting that our main estimates are not entirely driven by the urban sample.

\section{Conclusions}

This paper analyzes the causal effect of paternal and maternal unemployment on the health of children aged 0-17 in China, during a period of economic reforms that resulted in massive lay-offs and declining employment rates. The effect of parental unemployment is identified from changes in gender-specific local employment rates, controlling for local average earnings, local economic infrastructure, and local health facilities. Given the nature of the CHNS data, we are only able to estimate the shortrun health impacts of unemployment. We find that paternal unemployment has negative effects on child health, significantly increasing the incidence of low weightfor-age. Maternal unemployment, on the other hand, reduces the incidence of low weight-for-age, as well as the incidence of sickness and injuries and the use of health services.

Our results are in line with recent evidence on the child health impacts of parental unemployment in the US (Schaller and Zerpa 2019) and with evidence on the role of 
Table 8 Effect of parental unemployment on health of urban and rural children

\begin{tabular}{|c|c|c|c|c|}
\hline & (I) & (II) & (III) & (IV) \\
\hline & Weight-for-age & Low weight-for-age & $\begin{array}{l}\text { Sick/Injured last } \\
4 \text { weeks }\end{array}$ & Health care use \\
\hline & FE-IV & FE-IV & FE-IV & FE-IV \\
\hline \multicolumn{5}{|l|}{ Panel A: Rural } \\
\hline Mother Jobless & $0.560 *(0.317)$ & $-0.146^{* *}(0.067)$ & $-0.081(0.065)$ & $-0.137 * *(0.069)$ \\
\hline Father Jobless & $-0.324(0.423)$ & $0.162(0.122)$ & $0.079(0.070)$ & $0.286(0.214)$ \\
\hline$N$ & 3021 & 3021 & 2970 & 2798 \\
\hline$P$-value F-test & 0.192 & 0.067 & 0.187 & 0.096 \\
\hline F-stat first stage & 34.638 & 34.638 & 36.574 & 39.919 \\
\hline \multicolumn{5}{|l|}{ Panel B: Urban } \\
\hline Mother Jobless & $-0.305(1.025)$ & $-0.016(0.201)$ & $-0.477 * *(0.238)$ & $-0.119(0.230)$ \\
\hline Father Jobless & $-1.025(1.240)$ & $0.357(0.271)$ & $0.299(0.263)$ & $0.327(0.553)$ \\
\hline$N$ & 1201 & 1201 & 1152 & 1138 \\
\hline$P$-value F-test & 0.730 & 0.409 & 0.104 & 0.545 \\
\hline F-stat first stage & 5.658 & 5.658 & 4.601 & 3.755 \\
\hline Basic controls & $\mathrm{Y}$ & $\mathrm{Y}$ & $\mathrm{Y}$ & $\mathrm{Y}$ \\
\hline Additional controls & $\mathrm{Y}$ & $\mathrm{Y}$ & $\mathrm{Y}$ & $\mathrm{Y}$ \\
\hline
\end{tabular}

All estimations include child fixed effects and wave fixed effects. $N$ refers to the number of child-waves in the estimation. P-value F-test refers to the F-test that the coefficients for mother and father jobless are equal. Basic control variables are survey wave fixed effects, age of the child, age of both parents, number of children in the household, local average monthly wages, the local economic infrastructure index, and the number of clinics and hospitals in the community. Additional control variables are initial household wealth and parental education, interacted with survey dummies. Standard errors clustered by city/county are in parentheses. ${ }^{*}$ significant at 5 percent level, *significant at 10 percent level

maternal employment in explaining the cyclicality of infant health in a number of countries (e.g. Bhalotra (2010); Miller and Urdinola (2010)). Analyzing the main channels through which unemployment affects child health (income, insurance, time use, and children's diets), our estimates are imprecise but the results indicate that each of the channels may contribute to the differential child health impacts of maternal versus paternal unemployment. A new finding is that maternal unemployment increases children's dietary diversity score, whereas paternal unemployment reduces children's dietary diversity score, and reduces the intake of fats. To the best of our knowledge, this is the first evidence on the causal effect of parental unemployment on the diets of children aged 0-17, and it suggests that besides child care and health care, child health may be affected through changes in diets and nutrition.

In all, despite imprecision in our estimates, the picture that appears across all of our estimations is consistent, and shows that mothers' and fathers' unemployment have opposite impacts on child health. The evidence is in support of the idea that traditional gender roles drive these differences (Rege et al. 2011; Kalil and ZiolGuest 2008): working women in our sample earn less then men and women spend substantially more time on domestic chores and on child care, so that losing their job should result in a relatively smaller income loss while increasing maternal time 
investments in children. We find some evidence that the differential impact of maternal versus paternal unemployment is stronger for girls and low socioeconomic status children, but coefficient estimates are not significantly different across subsamples.

An important factor we are not able to assess is parental stress. The CHNS data do not include indicators of mental health, so that we cannot analyse whether job loss is associated with increased stress. Given traditional gender roles and the fact that paternal job loss is associated with greater loss of income, a greater increase in stress might explain (in part) why fathers' unemployment has negative health impacts (also see Artazcoz et al. 2004). Furthermore, we are not able to rule out ambient stress as a confounding factor. It is possible that changes in local employment rates affect children of working parents if they experience increased stress levels that reduce the quality and quantity of their child health investments. Whilst unobserved stress may therefore be a confounding factor, which may negatively bias our estimates, we generally find large negative health impacts from paternal unemployment that are unlikely to be driven entirely by ambient stress. Furthermore, unobserved stress cannot explain the opposing signs we find for the effects of fathers' and mothers' unemployment.

Since the reforms of State Owned Enterprises in China in the late 1990s led to stronger reductions in female employment than male employment, our results suggest that some dimensions of child health may have improved, with the benefits of maternal unemployment dominating. Still, many children suffered from negative health effects of paternal job loss, and in case of reforms with employment impacts concentrated among men, negative child health impacts could easily dominate. One such example is China's government announcement of an expected 1.8 million layoffs in the coal and steel industry through efforts to reduce overcapacity in industry $^{26}$, which is likely to affect male employment more heavily than female employment. A strong social safety net program, to compensate for income losses and support worker reallocation to other sectors, would be an important policy to mitigate negative child health impacts. Child feeding programs may be effective in particular to mitigate nutritional impacts more directly.

Acknowledgements The authors thank conference and seminar participants at the University of Göttingen, University of Reading, UNU-MERIT, the International Institute for Social Studies, and the Essen Health Conference for valuable comments and suggestions. This research uses data from China Health and Nutrition Survey (CHNS). We thank the National Institute for Nutrition and Health, China Center for Disease Control and Prevention, Carolina Population Center (P2C HD050924, T32 HD007168), the University of North Carolina at Chapel Hill, the NIH (R01HD30880, DK056350, R24 HD050924, and R01-HD38700) and the NIH Fogarty International Center (D43 TW009077, D43 TW007709) for financial support for the CHNS data collection and analysis files from 1989 to 2015 and future surveys. Any errors are our own.

\footnotetext{
${ }^{26}$ See Yao, Kevin and Meng Meng. 2016. "China expects to lay off 1.8 million workers in coal, steel sectors." Reuters, February 26. Retrieved from http://www.reuters.com/article/us-china-economyemployment-idUSKCN0W205X.
} 
Conflict of interest The authors declare that they have no conflict of interest.

Publisher's note: Springer Nature remains neutral with regard to jurisdictional claims in published maps and institutional affiliations.

Open Access This article is distributed under the terms of the Creative Commons Attribution 4.0 International License (http://creativecommons.org/licenses/by/4.0/), which permits unrestricted use, distribution, and reproduction in any medium, provided you give appropriate credit to the original author(s) and the source, provide a link to the Creative Commons license, and indicate if changes were made.

\section{Appendix}

Tables $9-12$

Table 9 Effect of parental unemployment on child health

\begin{tabular}{|c|c|c|c|c|}
\hline & \multicolumn{2}{|l|}{ Weight-for-age } & \multicolumn{2}{|c|}{ Low weight-for-age } \\
\hline & (I) & (II) & (III) & (IV) \\
\hline & FE-IV & FE-IV & FE-IV & FE-IV \\
\hline Father jobless & $-0.120(0.270)$ & & $0.116(0.077)$ & \\
\hline Mother jobless & & $0.249(0.255)$ & & $-0.039(0.078)$ \\
\hline$N$ & 4222 & 4222 & 4222 & 4222 \\
\hline \multirow[t]{3}{*}{ F-stat first stage } & 34.065 & 48.553 & 34.065 & 48.553 \\
\hline & \multicolumn{2}{|c|}{ Sick/Injured last 4 weeks } & \multicolumn{2}{|l|}{ Health care use } \\
\hline & FE-IV & FE-IV & FE-IV & FE-IV \\
\hline Father jobless & $-0.047(0.063)$ & & $0.142(0.199)$ & \\
\hline Mother jobless & & $-0.112 *(0.065)$ & & $-0.058(0.087)$ \\
\hline$N$ & 4122 & 4122 & 3936 & 3936 \\
\hline F-stat first stage & 34.723 & 44.944 & 33.213 & 47.880 \\
\hline Basic controls & $\mathrm{Y}$ & $\mathrm{Y}$ & $\mathrm{Y}$ & $\mathrm{Y}$ \\
\hline Additional controls & Y & $\mathrm{Y}$ & $\mathrm{Y}$ & $\mathrm{Y}$ \\
\hline
\end{tabular}

All estimations include child fixed effects. $N$ refers to the number of child-waves in the estimation. Basic control variables are survey wave fixed effects, age of the child, age of both parents, number of children in the household, local average monthly wages, the local economic infrastructure index, and the number of clinics and hospitals in the community. Additional control variables are initial household wealth and parental education, interacted with survey dummies. Standard errors clustered by city/county are in parentheses. *significant at 10 percent level 
Table 10 Effect of Parental Unemployment on Income and Health Insurance

\begin{tabular}{|c|c|c|c|c|}
\hline & \multicolumn{2}{|l|}{ Income } & \multicolumn{2}{|c|}{ Health insurance } \\
\hline & (I) & (II) & (III) & (IV) \\
\hline & FE-IV & FE-IV & FE-IV & FE-IV \\
\hline $\begin{array}{l}\text { Father } \\
\text { jobless }\end{array}$ & $\begin{array}{l}-9992.046 * * \\
(4211.066)\end{array}$ & & $\begin{array}{l}-0.469 * \\
(0.269)\end{array}$ & \\
\hline $\begin{array}{l}\text { Mother } \\
\text { jobless }\end{array}$ & & $\begin{array}{l}-5304.847 \\
(3509.031)\end{array}$ & & $\begin{array}{l}-0.335 \\
(0.239)\end{array}$ \\
\hline$N$ & 4222 & 4222 & 4023 & 4023 \\
\hline $\begin{array}{l}\text { F-stat } \\
\text { first stage }\end{array}$ & 34.065 & 48.553 & 36.287 & 48.468 \\
\hline $\begin{array}{l}\text { Basic } \\
\text { controls }\end{array}$ & $\mathrm{Y}$ & $\mathrm{Y}$ & $\mathrm{Y}$ & $\mathrm{Y}$ \\
\hline $\begin{array}{l}\text { Additional } \\
\text { controls }\end{array}$ & $\mathrm{Y}$ & $\mathrm{Y}$ & $\mathrm{Y}$ & $\mathrm{Y}$ \\
\hline
\end{tabular}

All estimations include child fixed effects. $N$ refers to the number of child-waves in the estimation. Basic control variables are survey wave fixed effects, age of the child, age of both parents, number of children in the household, local average monthly wages, the local economic infrastructure index, and the number of clinics and hospitals in the community. Additional control variables are initial household wealth and parental education, interacted with survey dummies. Estimations for child time use include only children aged 6 and older. Standard errors clustered by city/county are in parentheses. ** significant at 5 percent level, *significant at 10 percent level

Table 11 Effect of parental unemployment on time use

\begin{tabular}{|c|c|c|c|c|c|c|}
\hline & \multicolumn{2}{|c|}{ Child chores } & \multicolumn{2}{|c|}{ Mother chores } & \multicolumn{2}{|c|}{ Father chores } \\
\hline & (I) & (II) & (III) & (IV) & (V) & (VI) \\
\hline & FE-IV & FE-IV & FE-IV & FE-IV & FE-IV & FE-IV \\
\hline Father jobless & $\begin{array}{l}-11.274 \\
(11.846)\end{array}$ & & $\begin{array}{l}-54.543 \\
(41.802)\end{array}$ & & $\begin{array}{l}-6.222 \\
(22.402)\end{array}$ & \\
\hline Mother jobless & & $\begin{array}{l}-27.231 * * \\
(11.813)\end{array}$ & & $\begin{array}{l}-13.358 \\
(37.128)\end{array}$ & & $\begin{array}{l}-12.307 \\
(16.051)\end{array}$ \\
\hline$N$ & 3328 & 3328 & 4222 & 4222 & 4222 & 4222 \\
\hline $\begin{array}{l}\text { F-stat } \\
\text { first stage }\end{array}$ & 29.898 & 33.359 & 34.065 & 48.553 & 34.065 & 48.553 \\
\hline Basic controls & $\mathrm{Y}$ & Y & $\mathrm{Y}$ & $\mathrm{Y}$ & Y & $\mathrm{Y}$ \\
\hline $\begin{array}{l}\text { Additional } \\
\text { controls }\end{array}$ & $\mathrm{Y}$ & $\mathrm{Y}$ & $\mathrm{Y}$ & $\mathrm{Y}$ & $\mathrm{Y}$ & $\mathrm{Y}$ \\
\hline
\end{tabular}

All estimations include child fixed effects. $N$ refers to the number of child-waves in the estimation. Basic control variables are survey wave fixed effects, age of the child, age of both parents, number of children in the household, local average monthly wages, the local economic infrastructure index, and the number of clinics and hospitals in the community. Additional control variables are initial household wealth and parental education, interacted with survey dummies. Estimations for child time use include only children aged 6 and older. Standard errors clustered by city/county are in parentheses. **significant at 5 percent level 
Table 12 Effect of parental unemployment on child diets

\begin{tabular}{|c|c|c|c|c|c|c|c|c|}
\hline & \multicolumn{2}{|c|}{ Carbohydrates } & \multicolumn{2}{|l|}{ Fats } & \multicolumn{2}{|l|}{ Protein } & \multicolumn{2}{|c|}{ Dietary diversity } \\
\hline & (I) & (II) & (III) & (IV) & (V) & (VI) & (VII) & (VIII) \\
\hline & FE-IV & FE-IV & FE-IV & FE-IV & FE-IV & FE-IV & FE-IV & FE-IV \\
\hline $\begin{array}{l}\text { Father } \\
\text { jobless }\end{array}$ & $\begin{array}{l}-0.219 \\
(0.338)\end{array}$ & & $\begin{array}{l}-0.913^{* * * *} \\
(0.276)\end{array}$ & & $\begin{array}{l}-0.257 \\
(0.272)\end{array}$ & & $\begin{array}{l}-0.467 * \\
(0.273)\end{array}$ & \\
\hline $\begin{array}{l}\text { Mother } \\
\text { jobless }\end{array}$ & & $\begin{array}{l}-0.146 \\
(0.198)\end{array}$ & & $\begin{array}{l}-0.444 \\
(0.309)\end{array}$ & & $\begin{array}{l}-0.074 \\
(0.168)\end{array}$ & & $\begin{array}{l}0.240 \\
(0.281)\end{array}$ \\
\hline$N$ & 3950 & 3950 & 3950 & 3950 & 3950 & 3950 & 3950 & 3950 \\
\hline $\begin{array}{l}\text { F-stat } \\
\text { first stage }\end{array}$ & 30.167 & 50.858 & 30.167 & 50.858 & 30.167 & 50.858 & 30.167 & 50.858 \\
\hline $\begin{array}{l}\text { Basic } \\
\text { controls }\end{array}$ & $\mathrm{Y}$ & $\mathrm{Y}$ & $\mathrm{Y}$ & $\mathrm{Y}$ & $\mathrm{Y}$ & $\mathrm{Y}$ & $\mathrm{Y}$ & $\mathrm{Y}$ \\
\hline $\begin{array}{l}\text { Additional } \\
\text { controls }\end{array}$ & $\mathrm{Y}$ & $\mathrm{Y}$ & $\mathrm{Y}$ & $\mathrm{Y}$ & $\mathrm{Y}$ & $\mathrm{Y}$ & $\mathrm{Y}$ & $\mathrm{Y}$ \\
\hline
\end{tabular}

All estimations include child fixed effects. $N$ refers to the number of child-waves in the estimation. Basic control variables are survey wave fixed effects, age of the child, age of both parents, number of children in the household, local average monthly wages, the local economic infrastructure index, and the number of clinics and hospitals in the community. Additional control variables are initial household wealth and parental education, interacted with survey dummies. Standard errors clustered by city/county are in parentheses. ***significant at 1 percent level, *significant at 10 percent level

\section{References}

Agostinelli, F., \& Sorrenti, G. (2018). Money vs. time: family income, maternal labor supply, and child development. ECON Working Papers 273, Zurich: Department of Economics, University of Zurich.

Almond, D., \& Currie, J. (2011). Human Capital Development before Age Five, volume 4 of Handbook of Labor Economics. Amsterdam: Elsevier.

Angelini, V., \& Mierau, J. (2014). Born at the right time? Childhood health and the business cycle. Social Science and Medicine, 109, 35-43.

Artazcoz, L., Benach, J., Borrell, C., \& Cortes, I. (2004). Unemployment and mental health: understanding the interactions among gender, family roles, and social class. Journal of Public Health, 94(1), 82-88.

Baker, M., \& Milligan, K. (2008). Maternal employment, breastfeeding, and health: evidence from maternity leave mandates. Journal of Health Economics, 27(4), 871-887.

Barcellos, S. H., Carvalho, L. S., \& Lleras-Muney, A. (2014). Child gender and parental investments in India: are boys and girls treated differently? American Economic Journal: Applied Economics, 6(1), $157-189$.

Batis, C., Sotres-Alvarez, D., Gordon-Larsen, P., Mendez, M. A., Adair, L., \& Popkin, B. (2014). Longitudinal analysis of dietary patterns in Chinese adults from 1991 to 2009. British Journal of Nutrition, 111(8), 1441-1451.

Betcherman, G., \& Blunch, N.-H. (2008). The limited job prospects of displaced workers: evidence from two cities in china. Economic Change and Restructuring, 41(3), 187-207.

Bhalotra, S. (2010). Fatal fluctuations? Cyclicality in infant mortality in India. Journal of Development Economics, 93(1), 7-19.

Bramall, C. (2007). The industrialization of rural China. New York: Oxford University Press.

Cai, F., Park, A., \& Zhao, Y. (2008). The Chinese labor market in the reform era. In: L. Brandt \& T. G. Rawski, (Eds), China's great economic transformation (pp. 167-214). New York: Cambridge University Press.

Carneiro, P., Heckman, J. J., \& Vytlacil, E. J. (2011). Estimating marginal returns to education. American Economic Review, 101(6), 2754-2781.

Case, A., \& Paxson, C. (2010). Causes and consequences of early-life health. Demography, 47(1), 65-85.

Chen, F., Liu, H., Vikram, K., \& Guo, Y. (2015). For better or worse: the health implications of marriage separation due to migration in rural China. Demography, 52, 1321-1343. 
Chen, L., de Haan, A., Zhang, X., \& Warmerdam, W. (2011). Addressing vulnerability in an emerging economy: China's new cooperative medical scheme (ncms). Canadian Journal of Development Studies / Revue canadienne d'études du développement, 32(4), 399-413.

Chunming, C. (2000). Fat intake and nutritional status of children in China. American Journal of Clinical Nutrition, 72(suppl), 1368S-1372S.

Cole, T. J., Flegal, K. M., Nicholls, D., \& Jackson, A. A. (2007). Body mass index cut offs to define thinness in children and adolescents: international survey. BMJ, 335(7612), 194.

Cook, S. (2002). From rice bowl to safety net: insecurity and social protection during china?s transition. Development Policy Review, 20(5), 615-635.

Currie, J. (2009). Healthy, wealthy, and wise: socioeconomic status, poor health in childhood, and human capital development. Journal of Economic Literature, 41(1), 87-122.

Currie, J., Stabile, M., Manivong, P., \& Roos, L. L. (2010). Child health and young adult outcomes. Journal of Human Resources, 45(3), 517-548.

Das Gupta, M. (2008). Can biological factors like Hepatitis B explain the bulk of gender imbalance in China? A review of the evidence. World Bank Research Observer, 23(2), 201-217.

Dehejia, R., \& Lleras-Muney, A. (2004). Booms, busts, and babies' health. The Quarterly Journal of Economics, 119(3), 1091-1130.

Dong, X. (2003). 'China's urban labor market adjustment: A summary of literature review', Department of Economics Working Paper, University of Winnipeg.

Dong, X., \& Bowles, P. (2002). Segmentation and discrimination in China's emerging industrial labor market. China Economic Review, 13(2-3), 170-196.

FAO (2010). Guidelines for measuring household and individual dietary diversity. http://www.fao.org/3/ i1983e/i1983e00.htm.

Ferreira, F. H., \& Schady, N. (2009). Aggregate economic shocks, child schooling, and child health. The World Bank Research Observer, 24, 147-181.

Giles, J., Park, A., \& Cai, F. (2006). How has economic restructuring affected China's urban workers? The China Quarterly, 185, 61-95.

Gold, T., Hurst, W., Won, J., \& Li, Q. (2009). Laid-off workers in a workers state: Unemployment with Chinese characteristics. Springer.

Grossman, M. (2000). The human capital model. In: Culyer, A.J., \& Newhouse, J.P., (eds), Handbook of Health Economics, volume 1 of Handbook of Health Economics, chapter 7, 347-408. Amsterdam: Elsevier.

Hoddinott, J., \& Kinsey, B. (2001). Child growth in the time of drought. Oxford Bulletin of Economics and Statistics, 63(4), 409-436.

Jones-Smith, J. C., \& Popkin, B. M. (2010). Understanding community context and adult health changes in china: development of an urbanicity scale. Social Science and Medicine, 71, 1436-1446.

Kalil, A., \& Ziol-Guest, K. M. (2008). Parental employment circumstances and children's academic progress. Social Science Research, 37(2), 500-515.

Kuhn, A., Lalive, R., \& Zweimuller, J. (2009). The public health costs of job loss. Journal of Health Economics, 28(6), 1099-1115.

Lin, W., Liu, G. G., \& Chen, G. (2009). The urban resident basic medical insurance: a landmark reform towards universal coverage in China. Health economics, 18(S2), S83-S96.

Liu, H., \& Zhao, Z. (2014). Parental job loss and children's health: ten years after the massive layoff of the SOEs' workers in China. China Economic Review, 31, 303-319.

Liu, Y. (2002). Reforming China's urban health insurance system. Health policy, 60(2), 133-150.

Meng, X. (2012). Labor market outcomes and reforms in China. The Journal of Economic Perspectives, 26 (4), 75-102.

Miller, G., \& Urdinola, B. P. (2010). Cyclicality, mortality, and the value of time: the case of coffee price fluctuations and child survival in Colombia. The Journal of Political Economy, 118(1), 113-155.

Monheit, A.C., Grafova, I.B., \& Kumar, R. (2018). How does family health care use respond to economic shocks? realized and anticipated effects. Review of Economics of the Household. (In Press).

Mork, E., Sjogren, A., \& Svaleryd, H. (2014). Parental unemployment and child health. CESifo Economic Studies, 60(2), 366-401.

Page, M., Schaller, J., \& Simon, D. (2019). The effects of aggregate and gender-specific labor demand shocks on child health. Journal of Human Resources, 54(1), 37-78.

Pinger, P.R. (2015). Understanding the mechanisms behind intergenerational effects of economic distress. Mimeograph: University of Bonn. 
Popkin, B. M., Du, S., Zhai, F., \& Zhang, B. (2010). Cohort profile: The China health and nutrition survey-monitoring and understanding socio-economic and health change in China, 1989-2011. International journal of epidemiology, 39(6), 1435-1440.

Rege, M., Telle, K., \& Votruba, M. (2011). Parental job loss and children's school performance. The Review of Economic Studies, 78(4), 1462-1489.

Ruiz-Valenzuela, J. (2015). Job loss at home: children's school performance during the Great Recession in Spain. CEP Discussion Papers dp1364, Centre for Economic Performance, London: LSE.

Schaller, J., \& Zerpa, M. (2019). Short-run effects of parental job loss on child health. American Journal of Health Economics, 5(1), 8-41.

Steyn, N., Nel, J., Labadarios, D., Maunder, E., \& Kruger, H. (2014). Which dietary diversity indicator is best to assess micronutrient adequacy in children 1 to 9 y? Nutrition, 30(1), 55-60.

UNICEF (2015). Levels and trends in child malnutrition. UNICEF - WHO - World Bank Group joint child malnutrition estimates. Key findings of the 2015 edition. UNICEF, New York; WHO, Geneva; The World Bank, Washington DC.

Vodopivec, M., \& Tong, M.H. (2008). China: Improving unemployment insurance. SP Discussion Paper 0820, World Bank.

Ward, P. (2014). Measuring the level and inequality of wealth: an application to China. The Review of Income and Wealth, 60(4), 613-635.

WHO (2014). Success factors for women's and children's health: China. National Health and Family Planning Commission, Partnership for Maternal, Newborn \& Child Health, WHO, World Bank and Alliance for Health Policy and Systems Research. Geneva: World Health Organization.

World Bank. (2007). China's modernizing labor market: trends and emerging challenges. Washington, DC: World Bank.

Xu, X., Byles, J. E., Shi, Z., \& Hall, J. J. (2015). Evaluation of older chinese people's macronutrient intake status: results from the china health and nutrition survey. British Journal of Nutrition, 113(1), $159-171$.

Yang, W. (2013). China's new cooperative medical scheme and equity in access to health care: evidence from a longitudinal household survey. International Journal for Equity in Health, 12(1), 20.

Zhang, J., Han, J., Liu, P.-W., \& Zhao, Y. (2008). Trends in the gender earnings differential in urban China, 1988-2004. Industrial and Labor Relations Review, 61(2), 224-243.

Zhang, L., Yi, H., \& Rozelle, S. (2010). Good and bad news from China's new cooperative medical scheme. IDS bulletin, 41(4), 95-106. 